\title{
A Human Right to Legal Aid? - The Implications of Changes to the Legal Aid Scheme for Victims of Domestic Abuse
}

Shazia Choudhry and Jonathan Herring

Shazia Choudhry

Reader in Law, Queen Mary, University of London

School of Law

Queen Mary University of London

Mile End Road

London E1 4NS

02078823945

s.choudhry@qmul.ac.uk

Jonathan Herring

Professor of Law, University of Oxford

Exeter College

Oxford

OX1 3DP

01865-279600

Jon.herring@law.ox.ac.uk 


\begin{abstract}
This article explores the extent to which the human rights of victims of domestic violence have been interfered with by the restrictions on legal aid introduced by Legal Aid, Sentencing and Punishment of Offenders Act 2012. It argues that in failing to ensure that victims of domestic abuse have access to legal advice and representation their rights to a fair trial under Article 6 of the European Convention on Human Rights have been breached. Further, requiring them to litigate in person against an abuser constitutes a breach of their rights to respect for their private life under Article 8. Further still, the state in not ensuring that victims of domestic abuse have effective representation in disputes over child arrangements orders is breaching its obligation to protect them from further violence under Article 8.
\end{abstract}

\title{
Key Words
}

Legal Aid; Domestic Violence; Right to Fair Hearing; Human Rights; Litigant in Person

\section{Introduction}

One of the most profound duties of the state is to protect its citizens from violence. This is recognized in the European Convention on Human Rights which imposes positive obligations on the state to protect those facing violence and in particular those facing domestic abuse (Choudhry and Herring 2010). A broad range of measures is required if the state is to fulfil its obligations. These will include the effective enforcement of criminal law in terms of both 
protection and prosecution; the provision of emergency housing; and the availability of civil orders for protection.

This article will examine the last of these and the impact of the Legal Aid, Sentencing and Punishment of Offenders Act 2012 (LASPO) on the legal aid funding for victims of domestic abuse. The central argument is straight forward: the restrictions on access to legal aid for such victims constitute a breach of human rights. While LASPO largely facilitates the protection of the human rights of domestic abuse victims seeking orders for occupation and non-molestation orders under the Family Law Act 1996, we argue it does not for victims who are seeking financial orders or child arrangement orders. These orders cannot be separated from the package of measures that form part of the State responsibility to protect victims of domestic abuse.

We will start by summarizing briefly the relevant human rights obligations owed by the state to victims of domestic abuse, grouped under two primary headings: the right to a fair hearing and the right to protection from violence. We will then go on to examine the recent changes introduced by LASPO within the context of this summary.

\section{The Right to a Fair Hearing - Article 6 in General}

A number of human rights bodies (e.g. The UN Human Rights Committee (Thomas $v$ Jamaica), Views of 3 Nov 1997 II Rep of the Human Rights Committee, GAOR, $53^{\text {rd }}$ Sess, Supp No 40, UN Doc A/53/40, 1 (1998)) have held that the failure to provide legal aid can interfere with the right to pursue legal remedies and constitutes a human rights violation. 
Most directly relevant for English law, the European Convention on Human Rights (ECHR) and the European Court of Human Rights (ECtHR) have taken the same approach. Article 6 of the ECHR guarantees the right to a fair trial in both civil and criminal proceedings. This has been interpreted as providing for a general requirement of some measure of 'equality of arms' between the state and the individual or between the parties in the case, from which the right to legal assistance has been derived.

The applicability of Article 6 (1) in civil matters firstly depends on the existence of a 'dispute.' Secondly the dispute must relate to 'rights and obligations’ which, arguably at least, can be said to be recognised under domestic law. Lastly these 'rights and obligations' must be 'civil' ones within the meaning of the Convention, although Article 6 does not itself assign any specific content to them in the Contracting States’ legal systems (James and others v. United Kingdom, (1986) 8 EHRR 123, paragraph 81.) Some forms of hearing may therefore be excluded from the scope of Article 6, for example, those relating to refugee claims. In terms of family law, it has been accepted that disputes over residence and contact are regularly found by the European Court of Human Rights to involve rights under Article 8 (e.g. Hokkanen v Finland (1994) 19 EHRR 13).

\section{Granting of Legal Aid}

Article 6 (1) does not imply that the State must provide free legal aid for every dispute relating to a 'civil right.' (Airey $v$ Ireland [1979] 2 EHRR 305). There is a clear distinction between Article 6 (3)(c) - which guarantees the right to free legal aid in criminal proceedings subject to certain conditions - and Article 6 (1), which makes no reference to legal aid (Essaadi v. France, Application No. 49384/99, 26 February 2000). However, the Convention is intended to safeguard rights which are practical and effective, in particular the right of 
access to a court. Hence, Article 6 (1) may sometimes compel the State to provide for the assistance of a lawyer when such assistance proves indispensable for an effective access to court (Airey v. Ireland [1979] 2 EHRR 305). In Airey, an Irish woman had been trying to obtain a decree of judicial separation from her husband but was unable to do so. The Irish legal aid system did not provide legal assistance in such matters and the woman herself was not in a financial position to meet the costs involved. She claimed that there had been a violation of Article 6 (1) of the Convention, by reason of the fact that her right of access to a court was effectively denied.

The Court highlighted a number of circumstances that cumulatively led to a finding that Mrs. Airey had been denied an effective right of access to a court by the state’s refusal of legal aid:

(1) the proceedings, which concerned an application for a decree of judicial separation from the applicant's husband, were commenced by petition and conducted in the High Court, where the procedure was complex.

(2) litigation of the kind at issue, in addition to involving complicated points of law, necessitated proof of adultery, unnatural practices, or cruelty, which might have required the tendering of expert evidence or the calling and examining of witnesses.

(3) marital disputes often entailed an emotional involvement that was scarcely compatible with the degree of objectivity required by advocacy in court.

(4) the Court drew attention also to the fact that the applicant was from a humble background, had gone to work as a shop assistant at a young age before marrying and having four children, and had been unemployed for much of her life. 
In all the circumstances, the Court considered it most improbable that Mrs. Airey could effectively present her own case. It considered further that this view was corroborated by the fact that, in each of the 255 judicial separation proceedings initiated in Ireland between January 1972 and December 1978, the petitioner had been represented by a lawyer.

However, the Court also found that the right to access to a court is not absolute and may be subject to legitimate restrictions, including the imposing of financial contributions or requiring a case to be well-founded and not vexatious or frivolous. It accepted that in some cases the possibility of a person representing themselves in court would be sufficient to meet the requirements of Article 6. However, the court went on:

... Article 6 (1) may sometimes compel the state to provide for the assistance of a lawyer when such assistance proves indispensable for an effective access to court either because legal representation is rendered compulsory, as is done by the domestic law of certain Contracting States for various types of litigation, or by reason of the complexity of the procedure or of the case.

The question of whether or not Article 6 requires the provision of legal representation to an individual litigant will therefore depend upon the specific circumstances of the case. What has to be ascertained is whether, in the light of all the circumstances, the lack of legal aid would deprive the applicant of a fair hearing ((Airey v. Ireland [1979] 2 EHRR 305). This will depend, among other factors, on:

(1) the importance of what is at stake for the applicant (Steel and Morris v. the United Kingdom, (Application no. 68416/01). Fourth Section, February 15 2005, § 61); 
(2) the complexity of the relevant law or procedure (Airey v. Ireland [1979] 2 EHRR 305, $\S 24)$;

(3) the applicant's capacity to represent him or herself effectively (McVicar v. the United Kingdom (2002) 35 EHRR 21.; Steel and Morris v. the United Kingdom, (Application no. 68416/01). Fourth Section, February 15 2005)

(4) expert evidence is involved of a complex nature (Mantovanelli v France (1997) 24 EHRR 370);

(5) the existence of a statutory requirement to have legal representation Airey v. Ireland [1979] 2 EHRR 305).

It may also be permissible to impose conditions on the grant of legal aid based in particular on the following considerations, in addition to those cited previously:

(1) the financial situation of the litigant (Steel and Morris v. the United Kingdom);

(2) his or her prospects of success in the proceedings (Steel and Morris v. the United Kingdom).

Although Article 6 does not apply to the proceedings relating to the application for legal aid per se, the Convention is applicable to these proceedings to the extent that serious deficiencies in such proceedings may lead to arbitrary denial of free legal assistance or access to court. The procedure for legal aid application should therefore not be so complex as to put a disproportionate hindrance in the way of the applicant's right of access to a court. When a determination of the "reasonable prospects of success" of the case is made, the authority that decides on the legal aid application should not substitute for the court, for example, by engaging in interpretation of controversial legal issues pertinent to the merits of the case to be 
decided. However, the system established by the legislature must offer individuals substantial guarantees to protect them from arbitrariness (Gnahoré v. France (2000)34 EHRR $38 \S 41$; Del Sol v. France, (2002) 35 EHRR 38), § 26). It is therefore important to have due regard to the quality of a legal aid scheme within a State (Essaadi v. France, Application no. 49384/99, , 26 February 2002§ 31) and to verify whether the method chosen by the authorities is compatible with the Convention (e.g. Santambrogio v. Italy (2004) ECHR 430, $\S 52)$. It is also essential for the state to give reasons for refusing legal aid and to handle requests for legal aid with diligence (Tabor v. Poland, Appl. No. 12825/02, $15^{\text {th }}$ January $2008 \S \S 45-46)$.

A good example of the application of these principles is $P, C$ and $S v$. United Kingdom, (2002) 35 EHRR 32. The Court found a violation of Article 6 (1) where the applicants were denied free legal aid while contesting the severance of their parental rights in child abuse proceedings, because of the complexity of the case, the importance of what was at stake, and the highly emotional nature of the subject matter. The Court applied the tests in the Golder and Airey line of cases, recalling that free legal assistance may be necessary in civil matters in order to ensure that access to a court is both effective and fair. Here, $\mathrm{P}$ was forced to represent herself in child protection proceedings. The trial judge accepted that the case would have been conducted differently had she been given effective counsel. Assistance afforded to $\mathrm{P}$ by the counsel for the other parties and the latitude the judge granted $\mathrm{P}$ in presenting her case were considered no substitute for competent representation by a lawyer.

In addition, the refusal of legal aid to applicants with disabilities may also tend towards a finding that a breach of Article 6 has occurred. In RP and others $v$ United Kingdom [2013] 1 FLR 744 a mother with learning difficulties, who lacked capacity to litigate was denied legal 
representation in a public law case. This was held to breach her article 6 rights and it is worth noting the observations of the court in detail.

"65 In cases involving those with disabilities the court has permitted the domestic courts a certain margin of appreciation to enable them to make the relevant procedural arrangements to secure the good administration of justice and protect the health of the person concerned. This is in keeping with the United Nations Convention on the Rights of Persons with Disabilities, which requires States to provide appropriate accommodation to facilitate the role of disabled persons in legal proceedings...

66 It is clear that in the present case the proceedings were of the utmost importance to RP, who stood to lose both custody of and access to her only child. Moreover, while the issue at stake was relatively straightforward - whether or not RP had the skills necessary to enable her successfully to parent $\mathrm{KP}$ - the evidence which would have to be considered before the issue could be addressed was not. In particular, the court notes the significant quantity of expert reports, including expert medical and psychiatric reports, parenting assessment reports, and reports from contact sessions and observes the obvious difficulty an applicant with a learning disability would have in understanding both the content of these reports and the implications of the experts' findings.

67 In light of the above, and bearing in mind the requirement in the UN Convention that State parties provide appropriate accommodation to facilitate disabled persons' effective role in legal proceedings, the court considers that it was not only appropriate but also necessary for the United Kingdom to take measures to ensure that RP's best 
interests were represented in the childcare proceedings. Indeed, in view of its existing case-law the court considers that a failure to take measures to protect RP's interests might in itself have amounted to a violation of Art 6(1) of the European Convention (emphasis added).”

\section{Human Rights and Litigants in Person}

Litigants in person must be treated equally to those with legal representation if the requirements of Article 6 are to be met. This was well demonstrated by Cruz de Carvalho v. Portugal Application Number 18223/04, Judgment 10 July 2007. The applicant was prevented by the judge from interrogating witnesses and participating actively in the oral proceedings of his civil case due to the fact that he was not represented by a lawyer. The Court noted that this put him in a disadvantaged situation and breached his human rights. The notion of a fair trial, it was held, incorporates in itself the respect of the principle of equality of arms. In a civil case this includes the obligation to offer to every side the possibility reasonably to present their case. In the given case, the applicant, being informed that the representation of a lawyer is not obligatory as stipulated in domestic law, had chosen to represent himself, but he was not allowed and did not have the same procedural opportunities as the other side in the proceedings. The Court found that the principle of equality of arms has not been observed and consequently there has been a violation of Article $6 \S 1$ of the Convention.

The case, does, however demonstrate a potential difficulty in this area. Cross-examination by an abuser of a victim, could constitute a breach of the human rights of the victim under Article 8, as part of their right to respect for their private life, or in some cases Article 6, in so far as they are a party to the proceedings. In such a case the judge must take steps to ensure 
to ensure a fair trial takes place in so far as is consistent with the rights of the victim. That might involve the judge themselves being involved in the cross-examination or limitations on the style of cross-examination (e.g. with the judge restricting the litigant in person if their examination became improper: Re K and $H$ [2015] EWCA Civ 543). It might well be argued that in some cases of serious abuse it would be impossible for the examination to proceed in a way which protected the psychological integrity of the victim, as protected under Article 8 (Re K and H [2015] EWCA Civ 543).

\section{The Development Of Positive Obligations and The Implications For Article 6}

The ECtHR has developed a number of positive obligations upon Member States in relation to most of the rights in the ECHR. This has been particularly evident with regard to Articles

2, 3 and 8. However, claims made under these articles in conjunction with Article 6 have led to the development of a number of significant positive obligations with regard to the meaning of a fair trial and the implications for the provision of legal aid.

As a result, the positive obligations under articles 2 and 3 of the ECHR now include the duty to conduct effective investigations into deaths that may have been caused by state agents and allegations of ill-treatment. This may give rise to an obligation to provide legal aid to enable the family of the victim or the claimant to participate effectively in the investigation. An example of this is evidenced by the decision in Jordan v. United Kingdom (2003) 37 EHRR 52. Here, the Court found a violation of the state's procedural obligations under Article 2, due to the fact that the family members of a man unlawfully killed by the police were not given legal aid during the investigation. However, in Bubbins v. United Kingdom (2005) 41 EHRR 24 no violation of Article 2 was found, inter alia, because even though victims were refused 
legal aid, they were represented throughout the proceedings by a privately retained counsel.

Article 8 of the ECHR also provides 'significant procedural safeguards against inappropriate interferences with the substantive rights protected by article 8'. While the European Court of Human Rights has not yet found a breach of article 8 as a result of the refusal to grant legal aid, it has suggested that 'the considerations concerning access to legal aid may be relevant when assessing the adequacy of procedural protection under article 8 of the convention.'

\section{The Charter of Fundamental Rights and Freedoms}

Potential rights to legal aid are not restricted to ECHR claims. The Charter of Fundamental Rights of the EU requires member states and the institutions and bodies of the EU to comply with its provisions when they are implementing EU laws. Article 47 of the charter provides for the right to a fair hearing. Article 47(3) states that 'legal aid shall be made available to those who lack sufficient resources insofar as such aid is necessary to ensure effective access to justice.' However, article 52(3) of the charter provides that the scope of charter rights shall be the same as those in the ECHR and the 'explanation' relating to article 47 (2007/C 303/2) states that provision should be made for legal aid 'in accordance with the case law of the European Court of Human Rights' (see also the decisions of the Court of Justice of the EU in Case C-279/09 DEB 9 [2010] ECR I-13849 [33] and Case C-156/12 GREP (13 June 2012). This suggests that article 47 may not take litigants much further than article 6 of the ECHR (although see Aalto, Hofmann, Holopainen, Paunio, Pech, Sayers, Shelton and Ward 2014, 1272). There are also specific provisions for legal aid under EU law which cover proceedings at the Court of Justice (Articles 15-118 of the Rules of Procedure of the Court of Justice ([2012] OJ L265/1); cross border civil cases ( Directive 2003/8/EC ([2003] OJ L026/41); cross border maintenance obligations and immigration cases (Chapter V of 
Council Regulation 4/2009 [2009] OJ L007/1; Articles 15 and 16 of Council Directive 2005/85/EC [2005] OJ L326/13 and Directive 2008/115/EC [2008] OJ L348/98), all situations which may raise issues of domestic abuse (see Meyler and Woodhouse, 2013 for further discussion).

\section{The Right to Protection from Violence/Abuse}

The ECHR recognizes that there is right to be protected from violence. The Convention recognizes that the state has a duty to take reasonable steps to protect one person from abuse at the hands of another, where that abuse threatens an individual's rights under ECHR articles 2, 3 or article 8 . For example, Article 2 prohibits a state from intentionally and unlawfully taking life. But it does much more than that. It requires the state to protect citizens from a risk of death at the hands of others (Opuz v Turkey (2010) 50 EHRR 28). The same is true of the right to protection from torture or inhuman or degrading treatment under Article 3 and the right to respect for private life under Article 8 . That is because the state has an obligation to positively protect the rights of the citizen, regardless of the source of interference in their rights (Valiulienè v. Lithuania (application no. 33234/07, para 72). A state will infringe an individual's right under articles 2, 3 or 8 if it is aware that they are suffering the necessary degree of abuse at the hands of another and fails to take reasonable ( $Z \vee U K$ [2001] 2 FCR 246), adequate ( $A \vee U K$ [1998] 3 FCR 597, para 24) or effective ( $Z \vee U K$ [2001] 2 FCR 246, para 73) steps to protect that individual from interference in their rights ( $E \mathrm{v} U K$ [2002] 3 FCR 700). The obligation on the state is enhanced in cases where there the individual is vulnerable. The obligations imposed on the state include ensuring that there is an effective legal deterrent to protect victims from abuse; to ensure that there is proper legal investigation and prosecution of any infringement of the individual rights; and where necessary to intervene and remove a victim from a position where they are suffering conduct which is 
prohibited by one of the articles (Choudhry and Herring, 2010, chs 8 and 9). Hence States have been found to infringe Article 3 when they have been aware that a victim of domestic abuse is suffering violence but fail to take steps to protect her MC v Bulgaria (2005) 40 EHRR 20. Article 14, which prohibits discrimination in the protection of rights may also be relevant in some cases due to the fact that because domestic violence disproportionately impacts upon women.

The basic right to protection from violence and abuse are also found in the Istanbul Convention (The Council of Europe Convention on preventing and combating violence against women and domestic violence, CETS No.210.) In a series of cases the ECtHR has been willing to find the impact of abusive relationships as falling within article 3 or 8 (e.g. Opuz v Turkey (2010) 50 EHRR 28; Mikulic v Croatia Application no. 53176/99). As the Parliamentary Assembly, Council of Europe, Committee on Equal Opportunities for Women and Men (2002, para 12) put it:

It has been demonstrated that violence in the home is like a form of torture. The victims are injured physically and psychologically and humiliated in body and soul. Like torture, conjugal violence is something that goes on and on.

In Opuz v Turkey (2010) 50 EHRR 28 the failure to adequately with domestic violence amounted to sex discrimination. Reference was made to various international documents to support the view of CEDAW Committee that 'violence against women, including domestic violence, is a form of discrimination.' In Opuz it was emphasized that women were far more likely to be subject to domestic violence and so a systematic failure to respond to the issue 
disproportionately impacted on women (see also Mikulic v Croatia Application no. 53176/99).

The failure to respond to domestic violence was held to be a breach of both Article 3 and Article 14 (TM and CM v Moldova Application no. 26608/11). The significance of invoking Article 14 is that it enhances the obligation on the state to ensure there is protection from domestic abuse and making it harder to claim that it was not reasonable to protect the victim.

Much more can be said about the obligations of the state in this area, and we have offered here only a brief outline (see Choudhry and Herring 2010). It is virtually unarguable, that if a victim of domestic abuse was seeking a protective order, but was prevented from accessing the courts though an absence of legal aid the state would be failing in its positive duty to protect her from violence, as outlined above. The denial of access to legal advice and representation to victims of domestic abuse can, in such cases involve a breach of the rights of protection we have outlined.

We want, however, to bring out a key argument: that this can be just as true where the victim of domestic abuse is denied effective protection in the context of a dispute over contact or a financial dispute. To be clear, the argument in such a case is not simply (as we shall explore shortly) that the victim has been denied access to a fair hearing, but that her rights to protection under Articles 2, 3 and 8 can, in some cases also be breached. We will make two central points to establish this.

First, there is substantial evidence that child arrangements orders can be used as a way of continuing abuse of the victim. Understood in this way, the outcome of a child arrangement 
order can be seen as an important plank of the protection from the victim (typically the mother and child) from the abuse. Research has demonstrated that in contact court disputes the existence of domestic violence is the most common welfare issue (Coy, Scott, Tweedale \& Perks 2015; Women’s Aid 2016; All-Party Parliamentary Group on Domestic Violence 2016). A recent survey of the evidence (Coy, Scott, Tweedale \& Perks 2015) concluded:

contact proceedings are frequently invoked by perpetrators as a means of seeking to continue to control women and children. A wide range of studies has shown that judicial decisions about contact which fail to take safety into account endanger women and children physically and emotionally and in some cases where courts have allowed unsupervised contact with violent men, children have been killed.

There is a lot more that can be said about this issue (Women's Aid 2016; Hester this issue). However, it is clear that part of the state's positive obligation to protect victims of domestic abuse require it to ensure that contact arrangements are not used as a way of perpetuating the abuse or enabling new abuse to occur (Choudhry 2012). The responsibility of the state to protect victims of domestic violence requires it to ensure legal aid is provided so the courts are best placed to ensure appropriate protection is offered.

Second, accounts of victims of domestic abuse who have not had legal representation of their court hearings indicate that those hearings can themselves be abusive and a failure to provide protection from the abuse during the hearing can infringe their rights to protection under Article 8. In a study of victims of domestic abuse who then face cross-examination from their abusers in court (Coy, Scott, Tweedale and Perks 2015) quote one women who said "it’s like going through the abuse again” as a typical response to that experience. The found 
women being emotionally and psychologically ground down; panic; depressions and sleeplessness being caused by having the litigate against their former abuser without legal representation (see also All-Party Parliamentary Group on Domestic Violence 2016).

Having set out the human rights issue in relation to legal aid and victims of domestic abuse we now set out the current legal position.

\section{Legal Aid, LASPO and Domestic Abuse}

The current regulation of legal aid is found in Part 1 of Legal Aid Sentencing and Punishment of Offence Act 2012 (“LASPO”) and Civil Legal Aid (Procedure) Regulations 2012 (“the 2012 Regulations”). Under this legislation legal aid is provided for certain listed categories of case. In taking this approach it departs from the Access to Justice Act 1999 which provided civil legal aid to all matters, except for a list of excluded matters. A notable category of cases included with LASPO are "services which are provided to actual or potential services of domestic violence” (s9 and Part 1 Sch 1). The legislation make it clear that covers "civil legal services in relation to home rights, occupation orders, non-molestation orders, and injunctions following assault, battery or false imprisonment arising out of a family relationship.” (para 11) In other words the kinds of civil order a victim of domestic abuse might seek directly to protect themselves from domestic abuse.

Apart from applications for domestic violence protection orders the starting point is that legal aid is not available for other family matters, unless the applicant can show she falls into a limited exceptional category. That means that generally legal aid is not available for divorce or dissolution; financial orders on separation; disputes of children (including child 
arrangements orders and prohibited steps orders) (para 12(8)(a)). The exception to this general rule which is most relevant for our discussion is the following

“(1) Civil legal services provided to an adult (“A”) in relation to a matter arising out of a family relationship between A and another individual (“B”) where -

(a) there has been, or is a risk of, domestic violence between A and B, and

(b) A was, or is at risk of being, the victim of that domestic violence.” (para 12)

Domestic violence is defined as:

“any incident, or pattern of incidents, of controlling, coercive or threatening behaviour, violence or abuse (whether psychological, physical, sexual, financial or emotional) between individuals who are associated with each other.” (Legal Aid, Sentencing and Punishment of Offenders Act 2012, Sch 1, para 12(1)).

Section 12 of LASPO allow regulations to determine whether an individual is entitled to legal aid and it is under that provision that the 2012 Regulations were issued. Regulation 33 (as amended in 2014) lists what will constitute evidence of domestic violence or the risk of domestic violence. This list includes a conviction or caution or bail or bind over for a domestic violence offence; a protective injunction or undertaking; a letter from a member of a multi-agency risk assessment conference confirming the applicant was referred to the conference as a victim of domestic abuse and been considered by them; a finding of fact in court proceedings that there has been domestic violence; or a letter from a health care professional or social services department or a domestic violence support organisation who confirming they are satisfied the victim has been or is at risk of domestic violence. The 
details of the kind of evidence required are found in the regulations. The claim in this article is that these restrictions on who can prove they are or have been the victim of domestic abuse is an improper interference in the human rights of victims of domestic abuse.

\section{Problems with Complying with the Proof Requirements}

It is not surprising that the following the introduction of these restrictions there has been a severe cut back in the numbers of people obtain legal aid for family proceedings. And it seems the reductions are still occurring. The Ministry of Justice and Legal Aid Agency (2016) writing on the impact on civil litigation generally write:

'The implementation of the LASPO Act in April 2013 resulted in large reductions in legal help workload. Trends have since levelled out overall at around one third of pre-LASPO levels, although in the last quarter new matter starts were $11 \%$ lower than in the same period of 2014. Workloads in civil representation also fell substantially following the LASPO Act, though by a smaller proportion than legal help. They now appear to be stable overall at around two-thirds of pre-LASPO levels...'

In 2006-7 there had been 157, 719 certificates for legal representation in civil legal aid but by 2014-15 that had fallen to 92, 896. In relation to family matters, in 2009-2010, 308, 838 certificates for legal help had been granted. But by 2014-15 the number was 43, 805 legal help certificates. In relation to representation in 2010-11 there were 156, 968 family civil representations applications of which 131, 160 granted. The equivalent for 2014-2015, 87, 532 applications and 79854 granted. It is beyond doubt that there are many people with 
family law cases who would, prior to LASPO have received legal aid, but who as a result of the legislation, are not.

There is strong evidence that domestic violence is a major aspect of the kind of cases over which there is family litigation, in particular child contact disputes (Coy, Scott, Tweedale \& Perks 2015). It would, therefore, be expected that a significant number of applicants for such orders would, in theory, be eligible. The numbers are surprisingly low (Women’s Aid (2016). As a result, there are strong grounds for assuming that victims of domestic violence are not obtaining legal aid. Among activists on the ground, there is a widespread belief that this is due to the difficulties in proving domestic abuse in the way required by Regulation 33 . Women’s Aid (2015) found that 39\% of women who had been affected by domestic violence were unable to provide the necessary forms of evidence. In some cases it was practical difficulties in acquiring the evidence. In the words of one respondent: ““'I’m lost in finding out how to obtain all of these things”. In other cases, it is simply that the evidence on the accepted list did not exist. The particular difficulties that arise are as follows:

\section{The emphasis on public notification}

The regulations only permit certain forms of evidence of domestic abuse. The assumption of the regulations seems to be that all domestic violence will contact the police or other official body. As Hunter (2011) points out this is a false assumption because only $16 \%$ of domestic violence victims report the incident to the police and of these only $5 \%$ of cases lead to a conviction. Indeed Women's Aid (2015) says that the criminal justice evidence is the least commonly used form of evidence with only1.4\% of respondents to their study relying on an unspent conviction and the same percentage on evidence of a bind over and a caution. There 
is a substantial literature on the impacts of domestic abuse and these include feelings of insecurity and responsibility for the abuse. These may deter victims from seeking official assistance. The lack of adequate response from the authorities, particularly the police (although this has been improving in recent years) and fears that reporting abuse will lead to child protection proceedings, can all explain why no formal notification of domestic abuse may have taken place. Cultural barriers towards domestic violence and family solidarity may make notification of abuse to officials difficult. For all these reasons relying on the victim having made a revelation of the abuse to a public official at the time of the abuse problematic.

\section{Expense and delay in getting the evidence.}

There is evidence that some of the evidence can be costly to obtain. Emmerson and Platt (2014) found reports that GPs were charging $£ 50$ for the reports this case. Women’s Aid (2015) reported 22.2\% of women in their survey had been asked to pay for the reports, with $7.4 \%$ having to pay over $£ 50$. The organisation also found that $28 \%$ of respondents had to wait more than seven days to receive the evidence. In cases where an application is in relation to an urgent matter this may cause applicants to proceed without legal aid.

\section{2 year requirement}

The evidence has to relate to two years prior to the application. This has proved problematic (House of Commons Justice Committee 2015). The Women’s Aid (2015) Study found 23\% of their sample of women who had suffered domestic abuse only had evidence going back over two years. There are a number of situations where the impact of domestic abuse continues after an incident that occurred two years earlier. The most obvious one is where a 
perpetrator, imprisoned for abuse committed several years ago, is about to be released and either makes an application for contact with his child and/or the victim seeks a specific issue order prohibiting him from contacting the child. Another may be where a victim has separated from a seriously abusive relationship several years ago but the impact of the abuse is still sufficiently grave enough to prevent her from feeling able to face the perpetrator in court as a litigant of person. In such a case the impact of the domestic abuse will be on-going even though the incident took place several years ago. There is also the fact that the nature of domestic abuse is such that it is widely acknowledged that a significant proportion of victims of domestic abuse simply do not report it to law enforcement agencies and/or seek legal, medical advice and support from voluntary organisations. These women will not therefore be in a position to produce any of the listed evidence.

The two- year restriction has been challenged in the courts. The Government presented the following justification for the two year restriction in R(Rights of Women) $v$ Lord Chancellor: [2016] EWCA Civ 91

[t]he policy intention [of the domestic violence gateway] is to provide legal aid where an individual will be materially disadvantaged by facing their abuser in court, not simply to provide open-ended access to legal aid for domestic violence. The time limit provides a test of the on-going relevance of the abuse.

This is not a convincing argument. While sometimes domestic violence which occurred several years ago might no longer impact on a victim in presenting her case in court it will be in many cases. Placing an arbitrary time limit of two years as the limit to indicate the 'ongoing relevance' of the abuse is inappropriate and ignores the wealth of evidence as to the 
individual nature and impact of domestic abuse. While at first instance in R(Rights of Women) v Lord Chancellor, the government won the judicial review case it was accepted by the court there were "justified criticisms" and that an "urgent review needed". The Court of Appeal allowed the appeal, with the court accepting that Parliament had intended in LASPO that victims of domestic violence have access to legal aid and this was being denied by the restrictions of acceptable evidence in Regulation 33. The Court of Appeal explained:

32. Both this court and the court below were presented with a considerable body of evidence tending to show that potential applicants for legal aid had been (or were likely to be) refused legal aid in circumstances in which, it was submitted, Parliament had intended legal aid to be available. This evidence was partly specific, partly anecdotal and partly statistical.

45. There is... no obvious correlation between the passage of such a comparatively short period of time as 24 months and the harm to the victim of domestic violence disappearing or even significantly diminishing. No doubt the 24 month requirement serves the purposes of the statute as the Divisional Court considered them to be but as I have said those purposes are not the only purposes of the statute. Once it is accepted that part of the statutory purpose is to ensure that legal aid is available to (at any rate the great majority of) sufferers from domestic violence, one has to ask why it is that so many of them are excluded by virtue of the 24 month rule.

The Court placed emphasis on some particular examples of women who they believed Parliament must have intended should receive legal aid, but were not able to access it because of the two-year limitation in the Regulations. Such cases, the Court held, were ones where 
there was ample evidence that the applicant was a victim of domestic abuse and so should be entitled to legal aid, but was denied it by Regulations issued under Section 12 of LASPO. The Lord Chancellor in issuing those regulations were not permitted to create bars to accessing legal aid which did not appear in the primary legislation. The Court concluded:

51. I would therefore allow this appeal and, subject to any further argument about the detail of the form of order, in principle declare that regulation 33 is invalid insofar as it

a) requires verifications of domestic violence to be given within a 24 month period before any application for legal aid; and b) does not cater for victims of domestic violence who have suffered from financial abuse.

As a result of this litigation the Government passed the Civil Legal Aid (Procedure) (Amendment) Regulations 2016 which extended the period for evidence from two years to sixty months for most kinds of evidence. While clearly an improvement on the previous position, it is still not difficult to think of cases of serious domestic abuse, which will have an impact even after five years.

\section{Medical evidence requirements.}

One of the means of proof that is listed is that a doctor confirm that domestic violence has taken place. They are required to sign a document stating:

"I can confirm that the [injuries/condition] that I presented to you with on [insert date when you were examined by the health professional if known] were caused by domestic violence.” (Ministry of Justice 2015) 
This requires doctors to attest to something that they cannot. While they may be in a position to confirm the injuries were consistent with domestic violence, they are not in a position to confirm they were.

\section{Exceptional cases}

The concerns raised about the difficulties in establishing proof would be less concerning if there was "wriggle room” enabling victims of domestic violence to apply for legal aid even if they did not have the official kind of evidence required. In theory this is provided by the availability of exceptional funding. However, it seems this is used in only exceptional cases. For all categories of cases in 2014-15 there were only 1172 applications and on 226 granted. In family cases it seems to be very rare for the exceptional category to be used. The judiciary have been surprisingly unrestrained in expressing their concern. In MG v JG [2015] EWHC 564 (Fam) Mostyn J stated:

14. As the President explained in $Q v Q$ the number of annual cases where the safety net has been applied can be counted on the fingers of two hands. In the year to March 2014 there were 9. Indeed between December 2013 and March 2014 one solitary case was caught by the safety net. The President stated at para 14 "if the scheme is indeed working effectively, then it might be thought that the scheme is inadequate, for the proper demand is surely at a level very significantly greater than 8 or 9 cases a year." Thus it would be perfectly reasonable to describe this "safety net" as a fig leaf. MG and JG have not applied for exceptional funding under section 10(3)(b), no doubt taking the realistic view that any such application would be rejected summarily. 


\section{Finding a lawyer}

Even if legal aid is granted there can still be difficulties in finding a lawyer who deal with a legal aid family law case. The House of Commons Justice Committee (2015) found fourteen local authorities for which there were no lawyers taking on civil legal aid cases. The Women's Aid (2015) survey found 71\% of respondents who found it difficult or very difficult to find a legal aid solicitors. $23 \%$ had to travel more than 15 miles to access legal advice and an additional 34\% between 6 and 15 miles. As the number of legal aid cases reduces it becomes harder for firms to make the work worthwhile given the beaurocracy in accessing the legal aid and dealing with the legal aid authorities. That paperwork may be justifiable for a firm dealing with a large quantity of work, with a smaller number of cases it because less worth the effort and expense.

Having set out the difficulties in accessing legal aid it worth exploring the consequences of not being able to obtain legal aid for a family law case. Applicants in such cases have two choices. Not to litigate; to represent themselves; or fund their own litigation. 53\% of respondents took no action in relation to their family law problem as a result of not being able to apply for legal aid. $29 \%$ paid a solicitor privately and $28 \%$ represented themselves at court.

\section{Unrepresented litigants}

A notable consequences of the restrictions on legal aid has been the growth in unrepresented litigants. This has raised huge concerns with the judiciary. In MG v JG [2015] EWHC 564 (Fam) Mostyn J held: 
15 Since the reforms have taken effect there have been an appreciable number of cases which have demonstrated that the blithe assumption in the consultation paper (that the parties' emotional involvement in the case will not necessarily mean that they are unable to present it themselves, and that there is no reason to believe that such cases will be routinely legally complex) is unfounded. This was entirely predictable.

There is a long list of cases where the judiciary have been highly critical of the fact an unrepresented litigant has not been in a position to represent their case in court (Kinderis $v$ Kineriene [2013] EWHC 4139 (Fam); Re B (a child) (private law fact finding - unrepresented father) [2014] EWHC 700 (Fam); Q v Q [2014] EWFC 7; Q v Q (No. 2) [2014] EWFC 31; Re H [2014] EWFC B127; Re D (A Child) [2014] EWFC 39; CD v ED [2014] EWFC B153; Re D (A Child) (No. 2) [2015] EWFC 2; and Re K \& H (Children: Unrepresented Father: Cross- Examination of Child) [2015] EWFC 1). These produce "gross unfairness" as it was put in MG v JG [2015] EWHC 564. The House of Commons Justice Committee (2015, para 107) explained:

The family courts make decisions which often have life-long consequences for the children involved. The courts need the best evidence possible to make the right decisions; this will not be achieved by putting vulnerable witnesses through crossexamination by their abuser.

It is worth exploring the difficulties in more detail. 
First, there is the straight-forward point that non-trained individuals may fail to present the relevant arguments to the court. This may lead the court to not having access to important pieces of evidence or not having relevant factors presented to them. In particular they may lack the skills or the emotional detachment to undertake a suitable cross examination of witnesses, especially where the witness was in a close emotional relationship with them (House of Commons Justice Committee 2015). One study found that, in nearly all cases involving Litigants in Person, there had been inadequate compliance with the procedural requirements of litigation (Trinder, Hunter et al 2014). Hunter and Trinder (2015) in their study found only a tiny minority of litigants in person were able to competently deal with all matters of litigation. They go on to explain:

'Many LIPs did not grasp foundational legal principles or concepts such as the importance of disclosure or the expectation of negotiation or settlement to forestall contested hearings. Two key 'legal' tasks - the preparation of bundles and crossexamination - were beyond the capacity of most LIPs. The legally aided group had higher levels of drug, alcohol and mental health problems, and a higher proportion of non-English speakers requiring interpreters.'

Second, the parties may present irrelevant information and arguments to the court, swamping the court with material which is of no, or limited, legal relevance to the court. This may cause significant delay but also hinder the court in focussing on the essential arguments. The problems are well illustrated by Lindner v Rawlins [2015] EWCA Civ 61, where at para 34 Aikens LJ stated: 
'Yet again, the court was without any legal assistance and had to spend time researching the law for itself then attempting to apply it to the relevant facts in order to arrive at the correct legal answer. To do the latter exercise meant that the court itself had to trawl through a large amount of documents in the file. All this involves an expensive use of judicial time, which is in short supply as it is. Money may have been saved from the legal aid funds, but an equal amount of expense, if not more, has been incurred in terms of the costs of judges' and court time. The result is that there is, in fact, no economy at all. Worse, this way of dealing with cases runs the risk that a correct result will not be reached because the court does not have the legal assistance of counsel that it should have and the court has no other legal assistance available to it.’

Third, there may be a significant imbalance in the parties’ abilities to present their arguments, which a court might clearly favour (Mitchell 2015). One party may be more used to public speaking or communicating with professionals; one party may have more time and access to legal advice.

Fourth, it may be that in presenting their arguments badly the party creates a bad impression to the court, which would not arise if their arguments were presented on their behalf. $R e W$ (A Child) [2014] EWCA Civ 772 a self-representing mother had residencee of her child transferred to the father. The judge, upheld by the Court of Appeal found that the "overly emotional" mother "is worryingly obsessed by the abuse of the child by her paternal grandfather"; "is out of control, believing her own propaganda and convincing the child of it"; "misled the court by saying that it was the child rather than herself who struggled with the grandfather's abuse”. It is suggested these conclusions were largely based on the way the 
mother represented herself in court. Had she had a lawyer who could act as a buffer and explain her concerns in a calm way it is unlikely the court would have made the findings against here it did (Herring 2014).

\section{Conclusion}

There is now ample evidence that the impact of LASPO is having breaching the human rights of victims of domestic abuse is two ways. First, as has is becoming widely acknowledged, in too many cases the denial of legal aid has meant that a person has had to represent themselves and that has resulted in a breach of a fair trial under Article 6. As we have highlighted many litigants in person are not in a position to represent themselves in court and this is particularly true of victims of domestic violence. The courts have acknowledged this. For example, in MG and JG [2015] EWHC 564 (Fam), para 10 it was held:

'10. In this case it is my firm view that it is impossible for MG and JG to be expected to represent themselves having regard to the factual and legal issues at large. There would be a gross inequality of arms, and arguably a violation of their rights under Articles 6 and 8 of the European Convention on Human Rights and Article 47 of the European Charter of Fundamental Rights.'

In Re $H$ [2014] EWFC B12 Judge Hallam was dealing with an unrepresented mother with speech, hearing and learning difficulties. An official of the Legal Aid Agency stated that there would be no breach of convention rights were she to remain unfunded. Judge Hallam stated "I find that statement astounding.' (para 6) 
In some cases justice has only been possible through lawyers acting pro bono. Relying on this is an inadequate, given the responsibilities of the state to ensure Article 6 rights are met. As was stated in $M G \& J G v J F$ [2015] EWHC 564 (Fam).:

all responsibility for ensuring that the parents are able to participate effectively in the proceedings it has brought - to the goodwill, the charity, of the legal profession. This is, it might be thought, both unprincipled and unconscionable. Why should the State leave it to private individuals to ensure that the State is not in breach of the State's - the United Kingdom's - obligations under the Convention?"

Less attention has been paid to the second human rights argument we have made, namely that the state has a duty to protect victims of domestic abuse from breaches of the rights under Article 3 and 8 . By requiring parties to represent themselves the court proceedings themselves can be seen as a continuation of that breach. We have set out above how the experience of litigating in person or being litigated against in person can perpetuate the abuse of victims of domestic violence. This is not confined to applications for protection orders. Further, the outcome of applications for child contact arrangements and financial orders can also enable abuse to continue. The state and therefore the court has a positive duty under Articles 3 and 8 to ensure contact arrangements and financial orders do not lead to arrangements which expose the victim to further Article 3 type treatment and to ensure that their Article 8 rights to privacy and family life are not disproportionately interfered with. The provision of proper legal advice and representation are essential if the state is to fulfil its duty. We emphasise that there is a positive burden on the state to ensure that this protection is offered. It should not be for a claimant to prove that they are at risk of domestic abuse and so in need of protection, the duty is on the state to ensure those in need are protected. We 
believe the current provision mean that victims of domestic abuse or at risk of domestic abuse who fail to obtain legal aid to deal with disputes over children are having their Article 6 and Article 3 or 8 rights infringed

\section{References}

Aalto, P., Hofmann, H., Holopainen, L. Paunio, Pech, E., Sayers, L., Shelton, D., and Ward, A. (2014) ‘Art 47 - Right to an Effective Remedy’in, S. Peers, T. Hervey, A. Kenner \& J. Ward (Ed.), The EU Charter of Fundamental Rights and Freedoms, A Commentary. Oxford: Hart.

All-Party Parliamentary Group on Domestic Violence (2016). 'Domestic Abuse, Child Contact and the Family Courts. London: Hansard.

Coy, M. Scott, E., Tweedale, R. \& Perks, K. (2015) ‘It's like going through the abuse again’: domestic violence and women and children's (un)safety in private law contact proceedings, Journal of Social Welfare and Family Law, 37:1, 5.

Choudhry, S. \& Herring, J. (2010). European Human Rights and Family Law. Oxford: Hart Emmerson, D. and Platt, J. (2014) Legal Aid, Sentencing and Punishment of Offenders Act 2012: LASPO reviewed. Family Law 44: 515-520

Choudhry, S. 'Contact, Domestic Violence and the ECHR', Current Legal Issues, (2012) Oxford University Press

Herring, J. (2014) Alarm Bells. New Law Journal 1 August 2014, 9-11. 
House of Commons Justice Committee (2015) Impact Of Changes To Civil Legal Under Part 1 Of The Legal Aid, Sentencing and Punishment of Offenders Act 2012 HC 311, Eighth Report of Session 2014-15. London: TSO.

Hunter, R. (2011) Doing violence to family law, Journal of Social Welfare and Family Law, 33:4, 343-359

Meyler, F. and Woodhouse, S. (2013) 'Changing the immigration rules and withdrawing the 'currency’ of legal aid: the impact of LASPO 2012 on migrants and their families. Journal of Social Welfare and Family Law 35: 1, 55-78

Ministry of Justice (2015) Request to health professional for medical evidence of injuries/condition consistent with domestic violence London: Ministry of Justice.

Ministry of Justice and Legal Aid Agency (2016) Legal Aid Statistics in England and Wales October to December 2015. London: TSO.

Mitchell, J. (2015). Time past and time present: Part 1: LIPs and child disputes. Family Law 1205-1210.

Parliamentary Assembly, Council of Europe, Committee on Equal Opportunities for Women and Men (2012) Domestic Violence (2002) Brussells: Council of Europe.

Trinder, L., Hunter, R., Hutchings, E., Miles, J., Moorhead, R., Smith, L. Sefton, M., Hinchly, V., Bader, K. and Pearc, J. (2014) Litigants in person in private family law. London: Ministry of Justice.

Trinder, L. and Hunter, R. (2015) Access to justice? Litigants in person before and after LASPO. Family Law 535-541.

Women’s Aid (2015). Evidencing domestic violence. London: Women’s Aid. Women’s Aid (2016) Nineteen Child Homicides. London: Women’s Aid 